\title{
PENGEMBANGAN MODUL MOMENTUM, IMPULS DAN TUMBUKAN DENGAN STRATEGI CONCEPT MAPPING DI MADRASAH ALIYAH NEGERI
}

\author{
${ }^{1)}$ Siti Roudlotus Sa'idah, ${ }^{1)}$ Trapsilo Prihandono, ${ }^{1)}$ Sri Wahyuni \\ 1) Program Studi Pendidikan Fisika FKIP Universitas Jember \\ Email : roudlotussaidah@gmail.com
}

\begin{abstract}
One of physics material's character was abstract, that character caused the students got difficulties. Besides that, the unconsecutive material was becomes a weakness in the displays of material in physics books at school. One of solution to solve this problems was using the concept mapping module. The purposes of this research were to describe the validity of modules, effectiveness, and practicality. The research method used was 4D model which suggested by Thiagarajan, Semmel and Semmel. The result of this research was module classified as valid by the value of validity was $85,47 \%$, module was effective by value of retention $98,79 \%$, module classified as practical by value of student response was 67,71\%. Based on these data, it can be concluded that the module was very valid, effective and practical for used in learning.
\end{abstract}

Keyword: module, concept mapping, 4D model

\section{PENDAHULUAN}

Fisika merupakan salah satu bagian dari Ilmu Pengetahuan Alam (Hardini et al., 2013). Karakter materi fisika adalah bersifat konkret, namun ada pula yang bersifat abstrak (Fathurohman, 2014). Salah satu materi fisika yang memiliki karakter abstrak adalah materi momentum, impuls dan tumbukan sebab terjadi dalam waktu yang sangat singkat dan cepat (Sutrisno et al., 2015).

Materi yang bersifat abstrak mengakibatkan siswa kesulitan untuk menelaah konsep momentum (Kurniawan, 2014). Disamping itu, siswa masih mengalami kesalahan dalam memecahkan konsep yang abstrak (Farida, 2015).

Berdasarkan hasil wawancara yang dilakukan pada guru fisika di MAN 1 Jember, bahwa pengembangan modul fisika untuk siswa sudah dilakukan oleh guru, namun terkendala dalam pengaplikasiannya. Berdasarkan angket yang telah disebarkan kepada 32 siswa kelas X MIPA 1, $59 \%$ siswa menyatakan bahwa materi yang disampaikan pada buku fisika yang mereka gunakan sulit dipahami. Selain itu, $65 \%$ siswa berpendapat bahwa format buku fisika kurang menarik.

Salah satu kelemahan bahan ajar di sekolah adalah strategi pengorganisasian dan penyampaian isi dalam bahan ajar tidak terstruktur dengan baik dan kemasan kurang menarik (Kuswandari et al., 2013). Modul merupakan salah satu bentuk bahan ajar yang dapat digunakan sebagai alternatif penunjang pembelajaran (Purwanti dan Sunariningsih, 2015). Disamping itu, modul juga dapat berpengaruh positif terhadap hasil belajar siswa (Nilasari et al., 2016).

Pelaksanaan pembelajaran tidak lepas dari adanya strategi pembelajaran, misalnya strategi peta $\operatorname{konsep}($ concept map) (Nuryana et al., 2013). Konsep yang dipetakan dapat melatih siswa menerima informasi secara sistematis (Sari et al. 2015). Strategi peta konsep juga dapat 
meningkatkan hasil belajar siswa (Sari et al., 2013).

Penelitian relevan tentang penggunaan concept mapping dalam bahan ajar sudah pernah dilakukan oleh Fadilah et al. (2015) dengan hasil $73 \%$ siswa menyatakan lebih memahami materi apabila disajikan menggunakan peta konsep. Sari et al. (2015) dengan simpulan bahwa siswa sangat setuju dengan pembelajaran menggunakan bahan ajar concept mapping.

Berdasarkan uraian tentang karakteristik materi dan kelemahan bahan ajar, maka dengan menggunakan modul strategi peta konsep, diharapkan siswa dapat lebih memahami materi momentum, impuls dan tumbukan. Adapun tujuan dari penelitian ini antara lain: (1) mendeskripsikan validitas modul momentum, impuls, dan tumbukan dengan strategi concept mapping di Madrasah Aliyah Negeri; (2) mendeskripsikan efektivitas modul momentum, impuls, dan tumbukan dengan strategi concept mapping di Madrasah Aliyah Negeri; dan (3) mendeskripsikan kepraktisan modul momentum, impuls, dan tumbukan dengan strategi concept mapping di Madrasah Aliyah Negeri.

\section{METODE}

Jenis penelitian ini adalah penelitian pengembangan yang menghasilkan produk berupa modul momentum, impuls dan tumbukan dengan strategi concept mapping di MAN 1 Jember untuk kelas X semester genap tahun ajaran 2016/2017. Desain penelitian yang digunakan adalah model pengembangan 4-D oleh Thiagarajan, Semmel, dan Semmel (1974). Model ini terdiri dari empat tahapan pengembangan, yaitu define, design, develop, dan desseminate.

Tahap pendefinisian (Define) meliputi beberapa langkah pokok, yaitu setelah melakukan observasi awal, diperoleh: (a) buku yang digunakan di MAN 1 Jember dan penyebaran angket pada siswa, bahwa 59\% siswa menyatakan bahwa materi yang disampaikan pada buku fisika yang mereka gunakan sulit dipahami, $65 \%$ siswa berpendapat bahwa format buku fisika kurang menarik; (b) karakteristik siswa kelas X MAN 1 Jember bahwa 75\% siswa lebih suka belajar dengan cara menulis apa yang mereka pelajari, hal ini dapat membantu proses pemahaman mereka. Sehingga dengan menggunakan modul strategi concept mapping ini diharapkan siswa dapat belajar secara efektif sesuai dengan gaya belajarnya; (c) analisis tugas pada penelitian pengembangan ini diuraikan berdasarkan Kompetensi Inti (KI) dan Kompetensi Dasar (KD) materi momentum, impuls, dan tumbukan sesuai kurikulum 2013 revisi 2016; (d) analisis konsep atau materi yang peneliti tetapkan adalah momentum, impuls, dan tumbukan berdasarkan silabus dalam kurikulum 2013 revisi 2016; dan (e) berdasarkan analisis tugas dan analisis konsep yang telah ditetapkan kemudian digunakan sebagai acuan penyusunan perumusan indikator pencapaian hasil belajar dan tujuan pembelajaran sebagai penjabaran kompetensi inti dan kompetensi dasar.

Tahap perancangan (Design) terdiri dari empat langkah, yaitu: (a) penyusunan tes dilakukan dengan cara menyusun instrumen test pengetahuan dengan menggunakan teknik tes dalam bentuk post test disertai kisi-kisi soal dan penskoran yang disesuaikan dengan materi serta tujuan pembelajaran; (b) media yang digunakan dalam penelitian ini adalah modul momentum, impuls dan tumbukan, media lain yang digunakan dalam penelitian ini adalah video demonstrasi, kelereng atau bola, lilin mainan atau plastisin, benda disekitar siswa dalam kelas; (c) format modul yang digunakan adalah ukuran $\mathrm{A} 4$, ukuran huruf 11 point, dan bentuk huruf serif, format ini disesuaikan dengan buku yang umum digunakan siswa; dan (d) rancangan awal dilakukan dengan menganalisis materi dari sumber yang relevan, pembuatan cover modul, penyusunan isi modul, serta 
penyusunan perangkat pembelajaran lain (silabus, RPP, kisi-kisi soal postest, dan angket respon siswa).

Tahap pengembangan (Develop) bertujuan untuk menghasilkan sebuah produk yang telah direvisi berdasarkan hasil validasi oleh validator dan data yang diperoleh dari uji pengembangan produk meliputi: (a) validasi ahli dilakukan oleh tiga validator dari dosen Program Studi Pendidikan Fisika-Jurusan Pendidikan MIPA-Universitas Jember yang berkompeten dalam bidangnya berdasarkan beberapa indikator yaitu: (1) kelayakan isi; (2) kelayakan penyajian; (3) kebahasaan; dan (4) kegrafikaan atau kegrafisan. Data hasil validasi tersebut kemudian dianalisis dengan menggunakan rumus sebagai berikut:

$$
V_{-a h}=\frac{T S e}{T S h} \times 100 \%
$$

Keterangan :

$\mathrm{V}_{\text {-ah }}=$ Validasi ahli

Tse $=$ Total skor empirik yang dicapai berdasarkan penilaian ahli

$\mathrm{TSh}=$ Total skor yang diharapkan

Nilai $V_{\text {-ah }}$ atau nilai rata-rata total dirujuk pada interval penentuan tingkat kevalidan modul fisika dengan strategi concept mapping pada Tabel 1.

Tabel 1. Kriteria validitas

\begin{tabular}{|c|c|}
\hline Interval & Kategori Validitas \\
\hline $\begin{array}{l}85,01 \%- \\
100,00 \%\end{array}$ & $\begin{array}{l}\text { Sangat valid, atau dapat } \\
\text { digunakan tanpa revisi }\end{array}$ \\
\hline $\begin{array}{l}70,01 \%- \\
85,00 \%\end{array}$ & $\begin{array}{l}\text { Cukup valid, atau dapat } \\
\text { digunakan namun perlu } \\
\text { direvisi kecil }\end{array}$ \\
\hline $\begin{array}{l}50,01 \%- \\
70,00 \%\end{array}$ & $\begin{array}{l}\text { Kurang valid, disarankan } \\
\text { tidak dipergunakan karena } \\
\text { perlu revisi besar }\end{array}$ \\
\hline $\begin{array}{l}01,00 \%- \\
50,00 \%\end{array}$ & $\begin{array}{l}\text { Tidak valid, atau tidak } \\
\text { boleh dipergunakan }\end{array}$ \\
\hline
\end{tabular}

(b) Uji pengembangan bertujuan untuk mengetahui efektivitas dan kepraktisan modul pada kelas uji pengembangan melalui retensi siswa dan respon siswa. Siswa diberikan posttest setelah akhir pembelajaran kemudian angket untuk mengetahui respon/tanggapan dan perkembangan pengetahuan siswa setelah menggunakan modul yang dikembangkan.

Pengujian retensi dilakukan dengan memberikan tes sebanyak dua kali yaitu posttest dan tes retensi yang berselang satu minggu. Respon siswa diperoleh dengan memberikan angket respon kepada siswa yang berisi beberapa pertanyaan atau pernyataan yang harus diisi sesuai respon atau tanggapan masing-masing siswa. Data retensi dan data respon yang diperoleh tersebut, kemudian dianalisis dengan menggunakan rumus sebagai berikut.

a) Data retensi

$$
\% \text { Retensi }=\frac{\text { Hasil tes } 2}{\text { Hasil tes } 1} \times 100 \%
$$

Keterangan :

Hasil tes $2=$ nilai hasil tes retensi

Hasil tes $1=$ nilai hasil posttest

$$
\text { Selanjutnya retensi siswa }
$$

dikategorikan sesuai dengan Tabel 2.

Tabel 2. Kriteria daya ingat (retensi) siswa

\begin{tabular}{cc}
\hline Interval & Kategori Retensi(R) \\
\hline $\mathrm{R} \geq 75 \%$ & Sangat baik \\
$70 \%-79 \%$ & Baik \\
$60 \%-69 \%$ & Cukup \\
$50 \%-59 \%$ & Rendah \\
$\mathrm{R} \leq 59 \%$ & Sangat kurang \\
\hline
\end{tabular}

(Sumber: Syah, 2010: 118).

b) Data respon

Keterangan :

$$
P O A=\frac{R}{S M} \times 100 \%
$$

POA = persentase respon siswa

$\mathrm{R} \quad=$ proporsi jumlah siswa yang memilih setuju

$\mathrm{SM}=$ jumlah siswa

Selanjutnya data respon siswa dikategorikan berdasarkan kriteria pada Tabel 3 .

Tabel 3. Kriteria respon siswa

\begin{tabular}{cc}
\hline Interval Kriteria & Kategori \\
\hline $0 \%-20 \%$ & Sangat tidak menarik \\
$21 \%-40 \%$ & Kurang menarik \\
$41 \%-60 \%$ & Cukup \\
$61 \%-80 \%$ & Menarik \\
$81 \%-100 \%$ & Sangat menarik \\
\hline
\end{tabular}

(Sumber: Riduwan, 2011: 15).

Tahap penyebaran (Disseminate) Tahap ini merupakan tahap penggunaan 
perangkat yang telah dikembangkan pada skala yang lebih luas, misalnya di kelas lain, di sekolah lain, oleh guru yang lain. Namun peneliti tidak melakukan tahap ini dengan alasan penelitian yang dilakukan dibatasi pada uji kelayakan atau kevalidan (Fadilah et al., 2015; Pradana dan Triyanto, 2012; Sari, 2015; Noto, 2014; Yuanita et al., 2015).

\section{HASIL DAN PEMBAHASAN}

Hasil penelitian pengembangan ini adalah modul momentum, impuls dan tumbukan dengan strategi concept mapping untuk Madrasah Aliyah Negeri yang dikembangkan menggunakan model 4D oleh Thiagarajan yang telah dimodifikasi menjadi 3D (define, design, dan develop). Tahap pendefinisian (define) dilakukan analisis kurikulum dengan menganalisis kompetensi inti dan kompetensi dasar yang sesuai dengan konsep momentum, impuls dan tumbukan, serta penjabaran kompetensi tersebut kedalam tujuan pembelajaran. Tahap perancangan (design) dilakukan untuk memperoleh modul momentum, impuls dan tumbukan dengan strategi concept mapping. Desain yang diperoleh terdiri dari halaman sampul (cover), kata pengantar, petunjuk penggunaan modul, daftar isi, kegiatan belajar, penyajian materi, ayo mengingat, contoh soal, latihan mandiri, ayo bekerja, siapa Descartes, rangkuman, kunci latihan mandiri, asah otak, dan daftar pustaka. Tahap pengembangan (develop) diperoleh data validasi modul dan data hasil uji pengembangan. Data validasi dilakukan oleh tiga dosen ahli. Data hasil validasi ahli diperoleh dari instrumen validasi yang di check list oleh ahli sesuai dengan penilaian validator. Data hasil check list oleh ahli dianalisis dengan menggunakan perhitungan rerata. Skala yang digunakan adalah skala likert 1, 2, 3, 4, dan 5 dengan kriteria penilaian (1) tidak valid, (2) kurang valid, (3) cukup valid, (4) valid, dan (5) sangat valid. Hasil validasi dapat dilihat pada Tabel 4.

Tabel 4. Data hasil validasi ahli terhadap modul

\begin{tabular}{|c|c|c|c|c|}
\hline No. & Komponen & Validator 1 & Validator 2 & Validator 3 \\
\hline $\mathbf{1}$ & Kelayakan Isi & $84,29 \%$ & $84,29 \%$ & $82,86 \%$ \\
\hline 2 & Kebahasaan & $93,33 \%$ & $93,33 \%$ & $80,00 \%$ \\
\hline 3 & Penyajian & $82,50 \%$ & $82,50 \%$ & $82,50 \%$ \\
\hline \multirow[t]{4}{*}{4} & Kegrafikaan & $100,00 \%$ & $80,00 \%$ & $80,00 \%$ \\
\hline & Rerata tiap validator & $90,03 \%$ & $85,03 \%$ & $81,34 \%$ \\
\hline & Rerata keseluruhan & & $85,47 \%$ & \\
\hline & Kategori & & Sangat Valid & \\
\hline
\end{tabular}

Data hasil uji pengembangan adalah data efektifitas modul diperoleh dari hasil retensi yaitu data nilai post test dan nilai retensi test siswa dari kelas uji pengembangan setelah mengikuti pembelajaran menggunakan modul momentum, impuls dan tumbukan dengan strategi concept mapping yang telah dikembangkan oleh peneliti. Adapun data rerata skor yang diperoleh dapat dilihat pada Gambar 1.

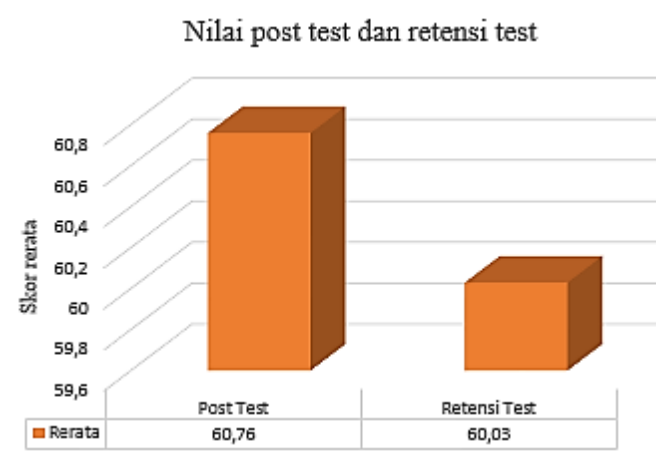

Gambar 1. Grafik rerata nilai post test dan retensi test 
Data hasil nilai posttest dan nilai retensi test siswa dapat dilihat pada Tabel 5.

Tabel 5. Data hasil retensi siswa

\begin{tabular}{ccccc}
\hline Komponen & Post test & Retensi & R & Kategori \\
\hline Rerata nilai & 60,76 & 60,03 & $98,79 \%$ & $\begin{array}{c}\text { Sangat } \\
\text { Baik }\end{array}$ \\
\hline
\end{tabular}

Data uji pengembangan selanjutnya adalah data kepraktisan modul yang diperoleh dari hasil respon siswa melalui angket. Data respon diperoleh dengan memberikan angket respon setelah selesai pembelajaran menggunakan modul momentum, impuls dan tumbukan dengan strategi concept mapping dan dapat dilihat pada Tabel 6.

Tabel 6. Data hasil respon siswa

\begin{tabular}{llcl}
\hline No & Aspek & $\begin{array}{c}\text { Percentage } \\
\text { of } \\
\text { Agreement }\end{array}$ & Kategori \\
\hline 1 & $\begin{array}{l}\text { Penyajian } \\
\text { modul }\end{array}$ & $67,59 \%$ & Menarik \\
\hline 2 & Kejelasan isi & $70,68 \%$ & Menarik \\
\hline 3 & $\begin{array}{l}\text { Ketercapaian } \\
\text { tujuan }\end{array}$ & $66,38 \%$ & Menarik \\
\hline & Rerata & $67,71 \%$ & Menarik \\
\hline
\end{tabular}

Berdasarkan validasi yang telah dilakukan oleh ketiga validator ahli, diperoleh rerata nilai validitas sebesar $85,47 \%$, sehingga modul yang dikembangkan tergolong sangat valid karena nilai validitas yang diperoleh berkisar pada rentang $85,01 \%-100,00 \%$.

Data efektivitas diperoleh dengan membandingkan rerata nilai retensi test dengan rerata nilai posttest. Nilai posttest siswa lebih tinggi setelah menggunakan modul concept mapping, sebagaimana penelitian yang dilakukan oleh Yahya et al. (2017) bahwa teknik concept mapping dapat meningkatkan nilai rata-rata posttest siswa secara signifikan. Analisis data efektifitas melalui perbandingan antara retensi test dan posttest sebesar 98,79\% dan tergolong sangat baik, dapat disimpulkan bahwa modul dengan strategi concept mapping yang dikembangkan sangat efektif digunakan dalam pembelajaran.
Data kepraktisan modul diperoleh melalui instrumen angket respon yang disebarkan kepada siswa kelas uji setelah pembelajaran menggunakan modul momentum, impuls dan tumbukan dengan strategi concept mapping. Kepraktisan modul dapat dilihat melalui angket respon sebagaimana penelitian Hamdunah (2015) bahwa berdasarkan angket, modul yang dikembangkan dikategorikan praktis jika nilai kepraktisannya (P) sebesar $60 \%<\mathrm{P} \leq 80 \%$. Analisis data terhadap kepraktisan modul concept mapping melalui angket respon yang telah disebarkan, diperoleh nilai $67,71 \%$. Berdasarkan nilai respon yang diperoleh, dapat diambil kesimpulan bahwa modul momentum, impuls dan tumbukan dengan strategi concept mapping yang dikembangkan dikategorikan menarik atau praktis digunakan dalam pembelajaran.

\section{SIMPULAN DAN SARAN}

Berdasarkan pembahasan hasil penelitian yang telah dilakukan, diperoleh simpulan sebagai berikut: (1) validitas modul yang diperoleh sebesar $85,47 \%$, modul yang dikembangkan memiliki kriteria sangat valid dan layak digunakan sebagai bahan ajar pada pokok bahasan momentum, impuls dan tumbukan; (2) efektivitas modul melalui retensi diperoleh sebesar 98,79\% dan memiliki kriteria sangat tinggi, dengan demikian modul yang dikembangkan efektif untuk meningkatkan daya ingat atau retensi siswa; dan (3) kepraktisan modul melalui respon diperoleh sebesar $67,71 \%$ dan memiliki kriteria menarik, dengan demikian modul yang dikembangkan praktis untuk digunakan sebagai bahan ajar pada materi momentum, impuls dan tumbukan.

Berdasarkan hasil penelitian dan pembahasan, maka saran yang dapat diberikan kepada penelitian selanjutnya adalah: (1) cover produk yang dikembangkan sebaiknya didesain lebih menarik untuk meningkatkan semangat siswa; (2) penelitian pengembangan sebaiknya dilakukan hingga tahap 
penyebaran ke sekolah lain supaya dapat diketahui keefektifan dan kepraktisan modul jika diterapkan pada karakter siswa yang berbeda; dan (3) retensi yang diujikan sebaiknya dilakukan dengan rentang yang lebih lama supaya lebih tampak perbedaan daya ingat siswa.

\section{DAFTAR PUSTAKA}

Akbar, S. 2013. Instrumen Perangkat Pembelajaran. Bandung: Remaja Rosdakarya.

Fadilah, R. E., Suratno., dan Wahyuni, D. 2015. Pengembangan bahan ajar sistem gerak manusia berbasis peta konsep dalam meningkatkan penguasaan konsep siswa kelas XI SMA di kabupaten Jember. Pancaran. 4(3): 41-50.

Farida, N. 2015. Analisis kesalahan siswa SMP kelas VIII dalam menyelesaikan masalah soal cerita Matematika. Aksioma. 4(2): 42-52.

Fathurohman, A. 2014. Analogi dalam pengajaran Fisika. Jurnal Inovasi dan Pembelajaran Fisika. 1(1): 7477.

Hamdunah. 2015. Praktikalitas pengembangan modul kontruktivisme dan website pada materi lingkaran dan bola. Lemma. 2(1): 35-42.

Hardini, R. R., Pujayanto., dan Ekawati, E. Y. 2013. Pengembangan bahan ajar IPA terpadu berbasis salingtemas untuk SMP kelas VII dengan tema ekosistem air tawar. Jurnal Materi dan Pembelajaran Fisika(JMPF). 3(1): 9-13.

Kurniawan, A. 2014. Penerapan model pembelajaran inkuiri terbimbing berbantuan CMAPTOOLS dalam pembelajaran fisika untuk meningkatkan kemampuan kognitif dan mempertahankan retensi siswa. Jurnal Penelitian Pendidikan. 14(1): 17-26.

Kuswandari, M., Sunarno, W., dan Supurwoko. 2013. Pengembangan bahan ajar Fisika SMA dengan pendekatan kontekstual pada materi pengukuran besaran Fisika. Jurnal Pendidikan Fisika. 1(2): 41-44.

Nilasari, E., Djatmika, E. T., dan Santoso, A. 2016. Pengaruh penggnaan modul pembelajaran kontekstual terhadap hasil belajar siswa kelas V sekolah dasar. Jurnal Pendidikan Teori, Penelitian dan Pengembangan. 1(7): 1399-1404.

Noto, M. S. 2014. Perangkat pembelajaran matematika berbasis SMART. Jurnal Penelitian Matematika. 3(1): 18-32.

Nuryana, I., Sulistyadi, K., dan Murtini, W. 2013. Pengaruh strategi pembelajaran concept map terhadap prestasi belajar dasar akuntansi keuangan II berdasarkan tipologi belajar. Jurnal Pendidikan Insan Mandiri. 2(1): 42-52.

Pradana, R. A., dan Triyanto. 2012. Efektivitas pengembangan modul pembelajaran CNC I pada program studi D3 teknik mesin Universitas Negeri Surabaya. Jurnal Pendidikan Teknik Mesin. 01(02): 48-57.

Purwanti, I., dan Sunariningsih. 2015. Meningkatkan hasil belajar siswa melalui pengembangan modul kearsipan berbasis guided inquiry. Jurnal Pendidikan Bisnis dan Manajemen. 01(01): 11-23. 
Riduwan. 2011. Skala Pengukuran Variabel-Variabel Penelitian. Bandung: Alfabeta.

Sari, N. A. A., Subiki., dan Wahyuni, S. 2015. Pengembangan bahan ajar pembelajaran fisika dengan concept mapping disertai authentic assessment pada pokok bahasan pemantulan cahaya di SMP. Jurnal Pembelajaran Fisika. 3(4): 317-323.

Sari, S., Sriyono., dan Desy, S. 2013. Perbedaan hasil belajar antara metode konvensional, peta konsep dan peta pikiran bagi siswa pada mata pelajaran fisika kelas X SMA Muhammadiyah Purworejo tahun pelajaran 2012/2013. Jurnal Radiasi. 3(2): $150-153$

Sutrisno, A. D., Samsudin, A., Liliawati, W., Kaniawati, I., dan Suhendi, E. 2015. Model pembelajaran two stay two stray(tsts) dan pemahaman siswa tentang konsep momentum dan impuls. Jurnal Pengajaran MIPA. 20(1): 38-42.

Syah, M. 2010. Psikologi Pendidikan dengan Pendekatan Baru Edisi Revisi. Bandung: Remaja Rosdakarya.

Yahya, I., Prihandono, T., dan Supriadi, B. 2017. Penerapan Concept Attainment disertai teknik Concept Mapping dalam pembelajaran Fisika di MA. Jurnal Pembelajaran Fisika. 6(1): 63-67.

Yuanita, D. I., Ahsan, H., dan Wiyono, K. 2015. Pengembangan panduan praktikum spektroskopi pada mata kuliah fisika modern. Jurnal Inovasi dan Pembelajaran Fisika. 2(1): 7787. 